\author{
III) Nordic Council \\ of Ministers
}

\title{
NORDIC ACTION ON CLIMATE CHANGE
}




\section{NORDIC ACTION ON CLIMATE CHANGE}

Timothy Bird

ANP 2017:766

ISBN 978-92-893-5181-2 (PRINT)

ISBN 978-92-893-5182-9 (PDF)

ISBN978-92-893-5183-6 (EPUB)

http://dx.doi.org/10.6027/ANP2017-766

(c) Nordisk Ministerråd 2017

Layout: Louise Jeppesen

Photos: unsplash.com

Photo p. 18: Hugi Olafsson

Photo p. 24: Sam Oekes

Printed in Denmark

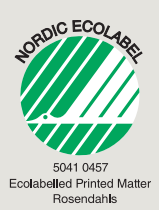

\section{Nordic co-operation}

Nordic co-operation is one of the world's most extensive forms of regional collaboration, involving Denmark, Finland, Iceland, Norway, Sweden, the Faroe Islands, Greenland, and Åland.

Nordic co-operation has firm traditions in politics, the economy, and culture. It plays an important role in European and international collaboration, and aims at creating a strong Nordic community in a strong Europe.

Nordic co-operation seeks to safeguard Nordic and regional interests and principles in the global community. Shared Nordic values help the region solidify its position as one of the world's most innovative and competitive.

\section{Nordic Council of Ministers}

Nordens Hus

Ved Stranden 18

DK-1061 Copenhagen K

www.norden.org

Download Nordic publications at www.norden.org/nordpub 


\section{NORDIC ACTION ON CLIMATE CHANGE}

Contents

5 FOREWORD

7 PROGRESSIVE POLICIES TO COMBAT CLIMATE CHANGE

12 DENMARK - world leader in wind power

14 FINLAND - building a bioeconomy

16 GREENLAND, THE FAROE ISLANDS AND ARCTIC ISSUES

- hydropower leads the way for renewable energy

18 ICELAND - utilising rich reserves of renewable energy

20 NORWAY - committed to global action

22 SWEDEN - investing in climate action and jobs

25 JOINT NORDIC SUPPORT FOR INTERNATIONAL ACTIONS

31 KEY NORDIC ORGANISATIONS AND INITIATIVES 


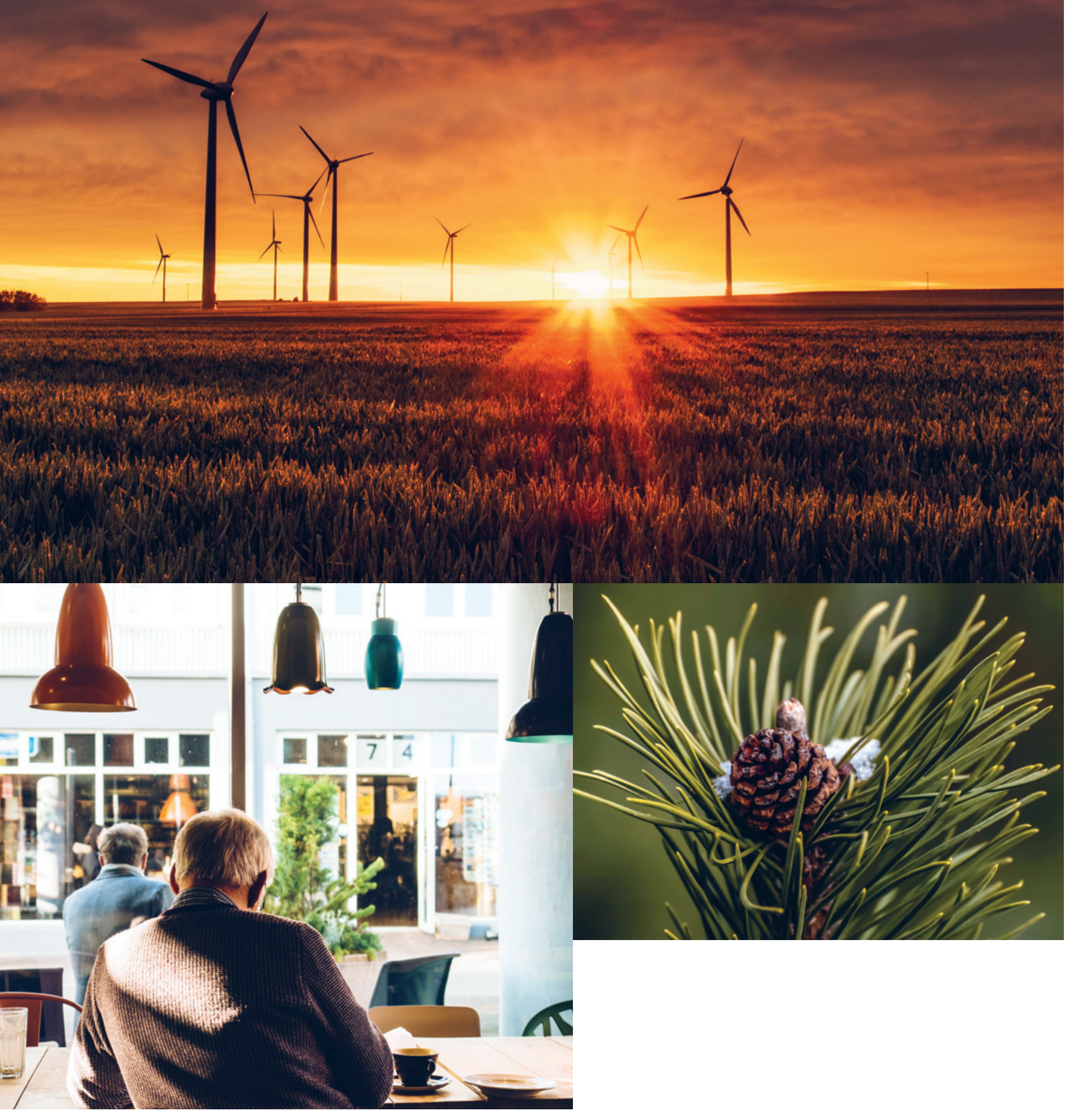




\section{FOREWORD}

The adoption and exceptionally quick entry into force of the Paris agreement is recognition of "the need for an effective and progressive response to the urgent threat of climate change on the basis of the best available scientific knowledge," as the agreement itself states.

In order to limit average global warming to below $2{ }^{\circ} \mathrm{C}$ relative to pre-industrial levels, the agreement calls for emissions of greenhouse gases to peak as soon as possible and that a balance is achieved between emissions and removals by sinks in the second half of this century.

A growing body of evidence indicates that effective mitigation actions can also improve economic performance, spur investment, create jobs and have positive impacts in other areas such as health and energy security in all types of economies. The rapid development in recent years in renewable energy technologies, where Nordic stakeholders make important contributions, is a good example.

This booklet presents actions taken by the Nordic countries to speed the transition to a sustainable low-carbon society. It shows how sustainable development is possible, with strong climate policies contributing to economic growth and job creation as well as environmental improvements. The Nordic countries successfully demonstrate how ambitious climate change mitigation targets and policies can be combined with high levels of human development.

We hope that our experiences will encourage others to instigate ambitious climate actions and realise opportunities to achieve green, climate-resilient growth around the world.

\section{Peer Stiansen}

Chair of the Nordic Working Group for

Global Climate Negotiations (NOAK) 


\section{PROGRESSIVE POLICIES TO COMBAT CLIMATE CHANGE}

The Nordic countries' forward-looking climate and energy policies have been designed on the basis that well-planned efforts to reduce greenhouse gas emissions can mitigate climate change while also promoting sustainable economic growth and employment. This decoupling of emissions from economic growth has already begun in the Nordic region. Nordic $\mathrm{CO}_{2}$ emissions per unit of electricity produced were one fifth of the global average in 2016, while total GDP in the same year grew by $2.2 \%$ to EUR 1,073 billion. This decoupling of emissions from economic growth has already begun in the Nordic Region (see graph on page 9).

In 2014 37\% of energy consumption in the region was from renewable sources, and $54 \%$ fossil-free. Ambitious emission reduction targets have also been set for future decades, with each country defining ambitious targets and visions for 2050 .

Along with the EU, the Nordic countries aim to achieve a reduction of at least $40 \%$ compared to 1990 by 2030 . Denmark's target is to have the entire energy supply covered by renewable energy, expected to result in a $75 \%$ reduction in greenhouse gas emissions. Finland has a vision of cutting emissions by $80 \%$ in 2050 as part of a wider international effort. Iceland has set the target of $50-75 \%$ cuts in net greenhouse gas emissions as an aspirational goal for 2050. Norway aims to be carbon-neutral by 2050 and Sweden plans to have zero net emissions of greenhouse gases in the atmosphere by 2045 .

\section{ENERGY EFFICIENCY - A HOT ISSUE IN THE COLD NORTH}

Energy consumption and greenhouse gas emission rates per capita are relatively high by global standards in the Nordic region, due to factors including the long, cold winters, long transportation distances in sparsely populated regions, high levels of material consumption, and the prevalence of energy-intensive industries.

These factors have long made energy efficiency a crucial issue. When it comes to heating Nordic homes, innovations including low-energy construction and district heating systems have cut annual carbon dioxide emissions from household heating systems to just 0.2 tonnes of $\mathrm{CO}_{2}$ per capita, compared to an average of 0.8 tonnes for OECD Europe.
The urgent need to reduce the use of fossil fuels has compounded efforts to improve the energy efficiency of industrial processes, buildings and transportation. At the same time all of the Nordic countries run wideranging clean energy research programmes, and Nordic governments support industrial investments in energy-saving and low-carbon technologies.

At the same time waste and organic materials such as logging residues have increasingly been used as an energy source in the Nordic countries in recent times, particularly in efficient combined heat and power systems. Biogas is increasingly being produced from agricultural residues and organic household waste, while waste that cannot be recovered and recycled can today be safely incinerated to generate energy instead of being dumped in landfill sites. 
The Nordic countries are already making good progress in the transition towards a more sustainable low-carbon society. Many successful Nordic climate policies and practical measures could be beneficially adapted for application in other regions, including success stories highlighted in this booklet.

The Nordic countries are also working actively to ensure swift and full implementation of the Paris Agreement, including a robust work programme by the end of 2018, and to promote global action and increased cooperation through the UNFCCC and other international climate policy forums.

\section{Making the most of renewable assets}

The Nordic countries are variously endowed with plentiful renewable energy resources including hydropower, wind power, geothermal energy and forest biomass (see graph on page 11). Each country is striving to make the most of the renewable resources available locally.

The high and widespread levels of renewable energy are due to the use of hydropower in
Norway and Sweden, and the effective use of biomass in combined heat and power plants in Finland and Sweden. Meanwhile Denmark has the highest share of wind power in the world, and Iceland has abundant geothermal energy.

National policies have incentivised the use of renewable energy sources even when they are not the cheapest option in the short term. The Nordic countries' advanced cross-border electricity market facilitates the greater use of renewable energy, since fluctuations in production often even out between regions, and can be balanced by flexible hydropower production.

The Nordic countries have historically pioneered energy and carbon taxes, providing further incentives to save energy and switch to renewable sources. Taxes on energy and fossil fuels generally remain significantly higher in the Nordic region than elsewhere in Europe.

National targets for reducing greenhouse gas emissions have been defined across the region together

\section{SOCIAL ACCEPTABILITY FOR GREEN POLICIES}

In addition to mitigating climate change, promoting local renewable energy sources also enhances energy security and reduces import dependency. Policies with such goals have gained widespread social acceptance. Nordic citizens are well aware of the related environmental issues, and municipalities are widely striving to promote green energy by setting their own targets and launching local initiatives.

The Nordic countries apply few energy subsidies, even for low-income households, who are instead supported through social welfare policies that enable them to meet their heating needs, while preserving incentives that encourage everyone to use less energy. The use of fossil fuels such as heating oil is declining, while biofuels, heat pumps and other greener alternatives are on the rise.

Progress towards these targets is carefully monitored at national level, and policies will be adjusted and expanded as necessary to keep on track.

In the transport sector national policies including tax frameworks aim to increase the use of renewable energy and promote low emission vehicles. All the Nordic countries aim to increase the market share of vehicle biofuels to $10 \%$ or more by 2020 in line with EU targets. 
with related action plans and initiatives, and will be agreed on as part of EU effort sharing. Individual countries' emission reduction targets for 2020 vary between $15 \%$ and $40 \%$ of 1990 benchmark figures. The 2030 target of reducing emissions by at least $40 \%$ implies that individual targets for the nontrading sector are expected to be agreed as part of effort-sharing, while the target for the trading sector is common for all countries participating in the European Emissions trading system. Each country has also mapped out far-sighted policies designed to work towards a shared Nordic vision for the decarbonisation of energy systems by 2050, and Nordic national targets are likely to remain among the most ambitious of all the EU countries.

\section{Green technology forerunners}

Nordic national policies have actively promoted $R \& D$ investments related to clean energy sources and energy-saving technologies. Building up local markets for green technologies helps new businesses to create new, green jobs and build up a base for exports that can be expected to boom as other regions seek ways to respond to the global climate challenge.
The Nordic countries have resolved to promote the spread of climate-friendly best available techniques. Their governments aim to support green technologies by encouraging public sector purchasers to serve as role models and help to build markets by favouring low-carbon options in areas such as transport, buildings and catering.

The Nordic countries and their shared financing institutions like the Nordic Environment Finance Corporation (NEFCO) and the Nordic Development Fund (NDF) are at the same time continuing to identify and support the implementation of climate-friendly renewable energy and energysaving schemes in developing countries both at the regional level (NEFCO) and beyond (NDF).

\section{Ambitious Nordic aims}

The Nordic countries have worked together for decades to make economic growth and welfare improvements compatible with ambitious environmental policies, while actively contributing to environmental improvements in the Nordic Region and beyond.

Decoupling environmental impact from economic growth

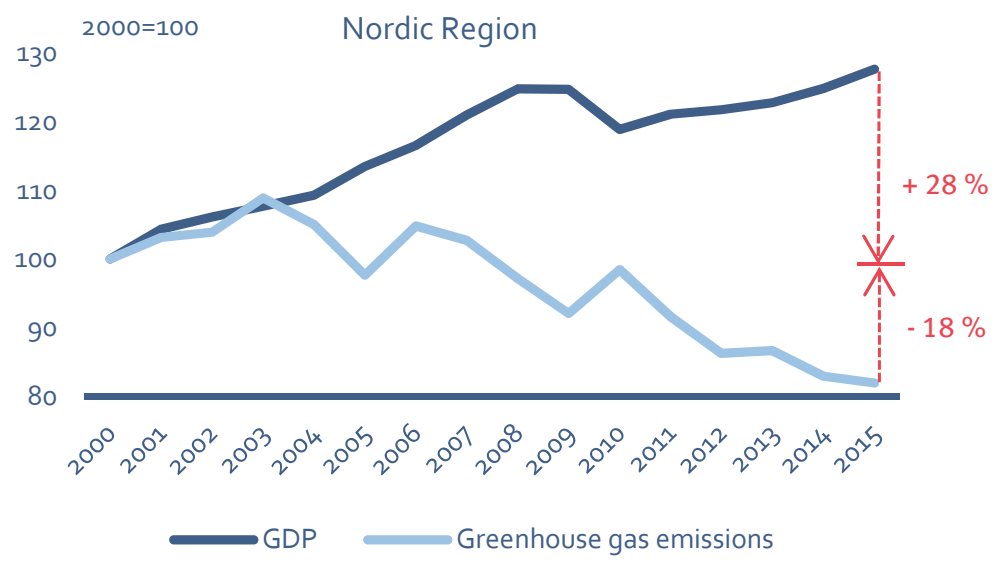

Source: Statistics Denmark 


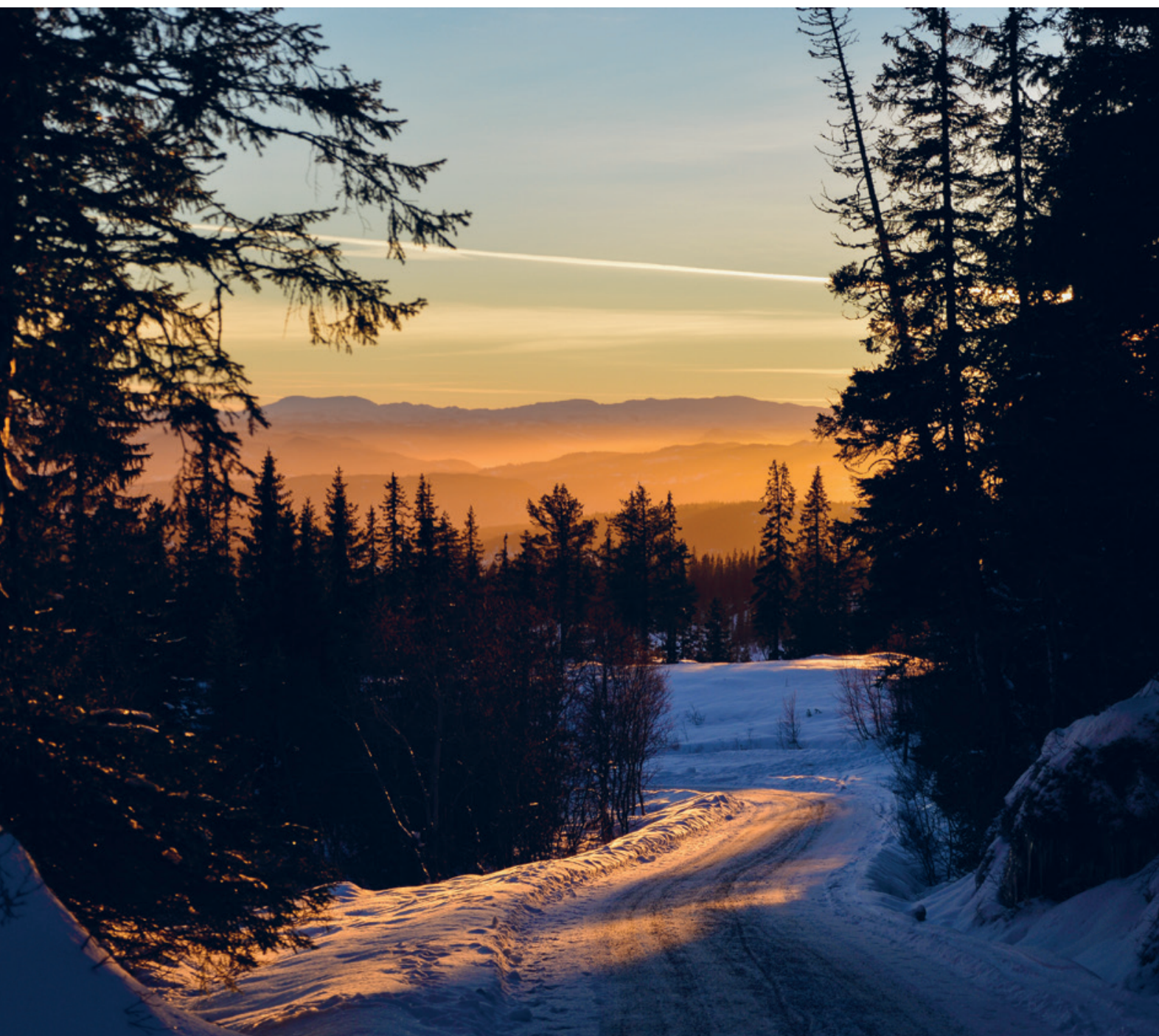

\section{NORDIC FORESTS AS CARBON SINKS}

Forests cover large areas of Northern Europe. The growing forest biomass and forest soils constitute a vast carbon sink that is important on a global scale.

Figures for the net impacts of land use, land use change and forestry (LULUCF) show that these factors result in negative greenhouse gas emissions in all the Nordic countries except Iceland. This is primarily because the region's forests are growing more rapidly than their biomass is being utilised.

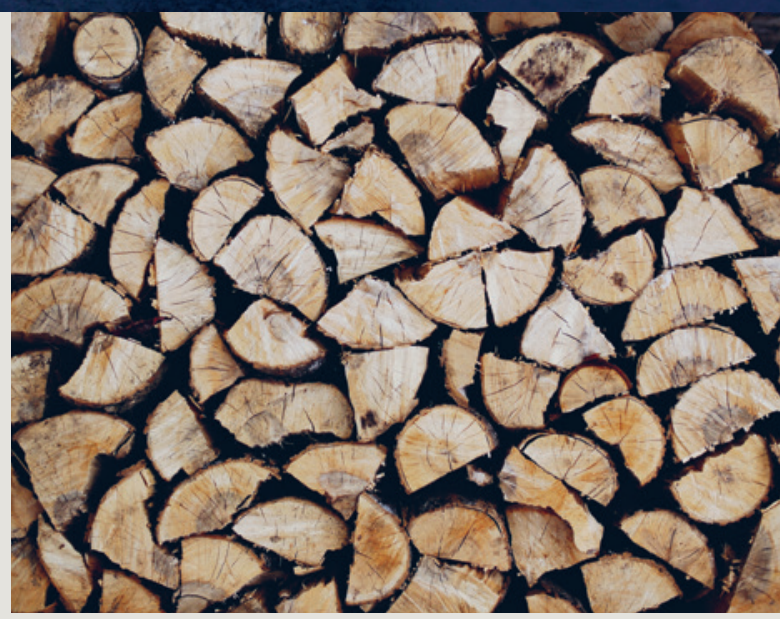


The Nordic Council of Ministers' environmental action plan for 2013-2018 aims to reduce greenhouse gas emissions to help achieve the goal of restricting global warming to an average of less than $2^{\circ} \mathrm{C}$, and thus limiting the consequent environmental and socioeconomic impacts.

The action plan emphasises the need to support innovative funding mechanisms such as the Green Climate Fund, as well as market-based mechanisms that can stimulate cost-effective emission reductions.

There have inevitably been fears that such ambitious policies could lead to "carbon leakage" in the private sector, if industries chose to shift location to countries with less stringent climate and energy policies; but the continued strong economic performance of the Nordic countries suggests that their progressive policies have not harmed business or welfare.

The Arctic region is particularly vulnerable to the impacts of climate change. Recent findings show that the Arctic is warming at more than twice the rate of global average resulting in serious global consequences. The joint Nordic action plan prioritises the work of the Arctic Council and the Barents Council on climate change and its effects on northern ecosystems. The Nordic countries have also resolved to support the International Maritime Organization's efforts to reduce emissions from shipping and participate in a concerted effort under the International Civil Aviation Organisation (ICAO) programme to avoid emissions from growth in air traffic after 2020.

Within wider international forums the Nordic countries will continue to push for a full implementation of the Paris Agreement, including finalising negotiations on a robust work programme by 2018. By pro-actively setting their own ambitious targets the Nordics aim to both fulfil their own international obligations, and demonstrate how it is possible to reduce emissions sustainably and cost-effectively. The Nordic countries are working together with partners in different regions in implementing the Paris Agreement, and will also support the the poorest and most vulnerable countries in their efforts.

\section{Nordic electricity generation mix (TWh) in 2013}

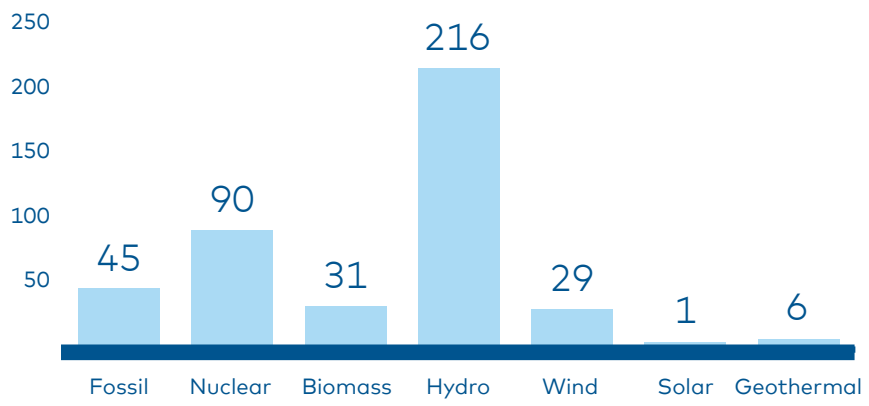




\section{DENMARK \\ WORLD LEADER IN WIND POWER}

Denmark has cut its greenhouse gas emissions by more than $27 \%$ since 1990 , and expects to achieve a $37 \%$ reduction by 2020 . Thanks to improved energy efficiency, $38 \%$ less energy was needed to produce each unit of Denmark's GDP in 2015 compared to 1990 - while the figure for total energy consumption in 2015 was the lowest for 32 years. In 2015 about $56 \%$ of Denmark's electricity came from renewable sources, including a world record of $42 \%$ from wind power. By 2020 the share of renewables is expected to rise to $84 \%$, with more than half of the country's electricity coming from wind power.
These achievements and expectations are based on initiatives defined in Denmark's 2012 Energy Agreement. Planned investments in energy efficiency, renewable energy and the energy system mean that by 2020 more than $40 \%$ of Denmark's total energy consumption can be expected to come from renewable sources.

Focus areas in addition to the further expansion of wind power capacity include energy taxes, improvements in the electricity grid, and the use of biofuels, district heating and surplus heat from industry.

\section{DANISH LESSONS ON ENERGY EFFICIENT BUILDINGS}

Thanks to the imposition of ever-stricter energy efficiency standards the energy demand of Denmark's new buildings has dropped by $80 \%$ since the 1970 s. Buildings' lifetime costs have also fallen, since savings due to improved energy performance exceed the related investment costs. Future requirements are announced well in advance to help the building industry adapt. Key factors include thermal insulation, air-tightness, use of daylight, optimisation of windows' heat loss/gain, and the energy efficiency of heating, lighting and ventilation.

Energy policy toolkits relating to the Danish energy model are available from the Danish Energy Agency's Energy Partnership Programme: www.ens.dk 


\section{Looking beyond 2020}

Denmark's long-term objective is to become independent of fossil fuels by 2050, when production of renewable energy should equal total energy consumption.

The 2012 Energy Agreement obliges all parties to the agreement to start setting up post-2020 initiatives by 2018 , with assistance from a new Energy Commission established by the Danish Government in 2015. These are in the process of elaboration.

The Climate Change Act enacted in June 2014 forms another key element in the strategic framework for Denmark's climate and energy policies. An independent Climate Council has subsequently been established, consisting of experts from key

\section{SAMS $\varnothing$ - AN ISLAND SHOWCASE FOR GREEN ENERGY}

The island of Samsø, with its farming community of about 4,000 inhabitants, has become a showcase for Danish efforts to switch to green energy using local resources. Community-owned wind turbines today produce more than enough electricity to meet the islanders' annual needs. About $70 \%$ of the island's heating needs are met by renewable sources, since most homes are connected to district heating systems fuelled by surplus straw, while other households are increasingly using solar panels, heat pumps and wood pellet boilers.

Samsø's Energy Academy aims to make the island totally fossil-fuel-free by 2030 , following further heating conversions and a switch to electric cars and biofuel-powered vehicles. The academy is frequently visited by environmental and energy experts from around the world. Samsø: energiakadamiet.dk fields who will regularly recommend policy initiatives. The Minister for Energy, Utilities and Climate will annually report on progress towards strategic emission reduction targets.

\section{Putting wind power at the centre of the electricity supply}

Denmark is endowed with favourable conditions for utilising winds power, including frequent moderate winds and shallow coastal waters. The wind power industry has become a major employer, accounting for more than $4 \%$ of Danish exports.

Some 5,000 wind turbines account for over $40 \%$ of Danish electricity consumption. Major ongoing offshore and onshore wind power developments are expected to raise this share to $53-59 \%$ by 2020. The large-scale deployment of wind power is supported by government backing for research and innovation and feed-in tariffs to guarantee developers' return on investments.

As a wind power pioneer Denmark has learnt many valuable lessons. Turbines should always be sited with due regard to environmental, economic and social impacts. Transparent public consultation processes are vital. The bureaucracy encountered by developers must be streamlined. Regulations governing wind-friendly grid investments must effectively share costs between investors and consumers.

Denmark has a one-stop-shop planning process for offshore schemes, and onshore developments benefit from assistance provided to local authorities by the Wind Turbine Secretariat.

Since wind power is by nature variable, Denmark has needed to reshape its energy supply system accordingly. Strong grid interconnectors guarantee flexibility and security of supply. A well-functioning "power exchange" market encourages producers to adapt to fluctuating demand. An independent transmission system operator plays a vital role in the successful integration of wind power into the national energy system. 
Wood-based energy is largely produced in forest industries and for combined heat and power and district heating schemes, already accounting for almost a quarter of Finland's total energy use. Finland's forests also act as a considerable carbon sink. Their total annual growth greatly exceeds total fellings. Over the years the annual net sinks calculated for Finland's land use, land use change and forestry sector (LULUCF) amounted to $20-60 \%$ of the country's annual greenhouse gas emissions.

\section{Ambitious but achievable targets}

The long-term goal is for the energy system to become carbon neutral and to be strongly based on renewable energy sources. Relevant and concrete measures and goals for near-term energy and climate policy are set out in the national energy and climate strategy (2016). The share of renewable energy of final energy consumption will rise to over $50 \%$ in the 2020 s. The domestic use of imported oil, i.e. petrol, diesel, fuel oil as well as jet fuel and kerosene will be halved during the 2020s compared to the total amount of energy in 2005.

The government meanwhile provides wide-ranging support for Finland's clean technology sector. The Cleantech Finland network strives to promote and export Finnish innovations in key technical fields including energy efficiency and renewable energy. Finland's national Programme to Promote Sustainable Consumption and Production particularly focuses on innovative projects designed to reduce climate impacts in three key sectors: housing, food and transportation.

Finland has also pioneered in the systematic planning of climate adaptation measures. A groundbreaking national strategy was first adopted in 2005, assessing challenges and allocating responsibility for anticipatory measures in key sectors. On the basis of evaluations and progress reports the strategy has been updated in 2014 as Finland's National Climate Change Adaptation Plan 2022.

\section{PIONEERING FINNISH MUNICIPALITIES}

Nearly all Finnish municipalities of more than 50,000 inhabitants have prepared a climate strategy. More than 30 Finnish municipalities both big and small - are committed to carbon neutrality or to cutting emissions by $80 \%$ of 2007 levels by 2030.

Through the Carbon Neutral Municipalities (HINKU in Finnish) project, several Finnish municipalities have committed themselves to reducing their greenhouse gas (GHG) emissions more extensively and more rapidly than would be required according to current EU targets and eventually to become carbon neutral. Currently 36 Finnish municipalities are involved - and more are likely to come. The project brings together municipalities, businesses, residents and experts in a unique way to devise and tailor new cost-effective solutions to reduce greenhouse gas emissions at municipal level.

During the project since 2007 the HINKU municipalities have reduced their GHG emissions on average by $29 \%$. Changes have been achieved especially by replacing fossil fuels with renewable energy and saving energy. The future goal is to join forces with larger Finnish cities to accelerate the transition towards a low-carbon society in Finland and also abroad.

The HINKU scheme is based on the idea that emission-saving investments invariably lead to cost savings in the longer term, and that local businesses that pioneer such developments put themselves in a good position to exploit growing future markets.

Carbon Neutral Municipalities Project: www.hinku-foorumi.fi 


\section{GREENLAND, THE FAROE ISLANDS AND ARCTIC ISSUES HYDROPOWER LEADS THE WAY FOR RENEWABLE ENERGY}

Greenland, home to the northern hemisphere's largest icecap, icebergs and polar bears, has become a symbol of global warming and climate change. Greenland is therefore acutely aware of the changing climate and is preparing to fully transition from fossil fuels to renewable energy.

Roughly $70 \%$ of Greenland's power supply (heat and electricity) is based on renewable energy. Within the next few years that figure will increase substantially, eventually reaching $100 \%$.

Greenland's public utility company (Nukissiorfiit), generates most of its energy supply from hydropower, in which Greenland has invested heavily in recent decades. Today almost all electricity demand is generated from hydropower (81.3\% in 2015).

Additionally, district heating has for a long time been a priority, resulting in well-developed district heating networks in several of Greenland's larger towns. The heat supplied is sourced from waste incinerators and heat generated as a bi-product at diesel fuelled power generators, as well as electric boilers powered by hydropower.

\section{Modern and efficient energy sector}

The government of Greenland put the final touches to a comprehensive sector plan for public energy and water supply for autumn 2017 publication. The main themes of the sector plan are fair and equal prices for all, regardless of where people choose to live, a transition to $100 \%$ renewables, and modernisation of the energy sector.

For Greenland to meet its goal of $100 \%$ renewable energy, it will undergo a modernisation of its energy sector, which includes a push to increase energy efficiency throughout the energy sector. Modernisa-

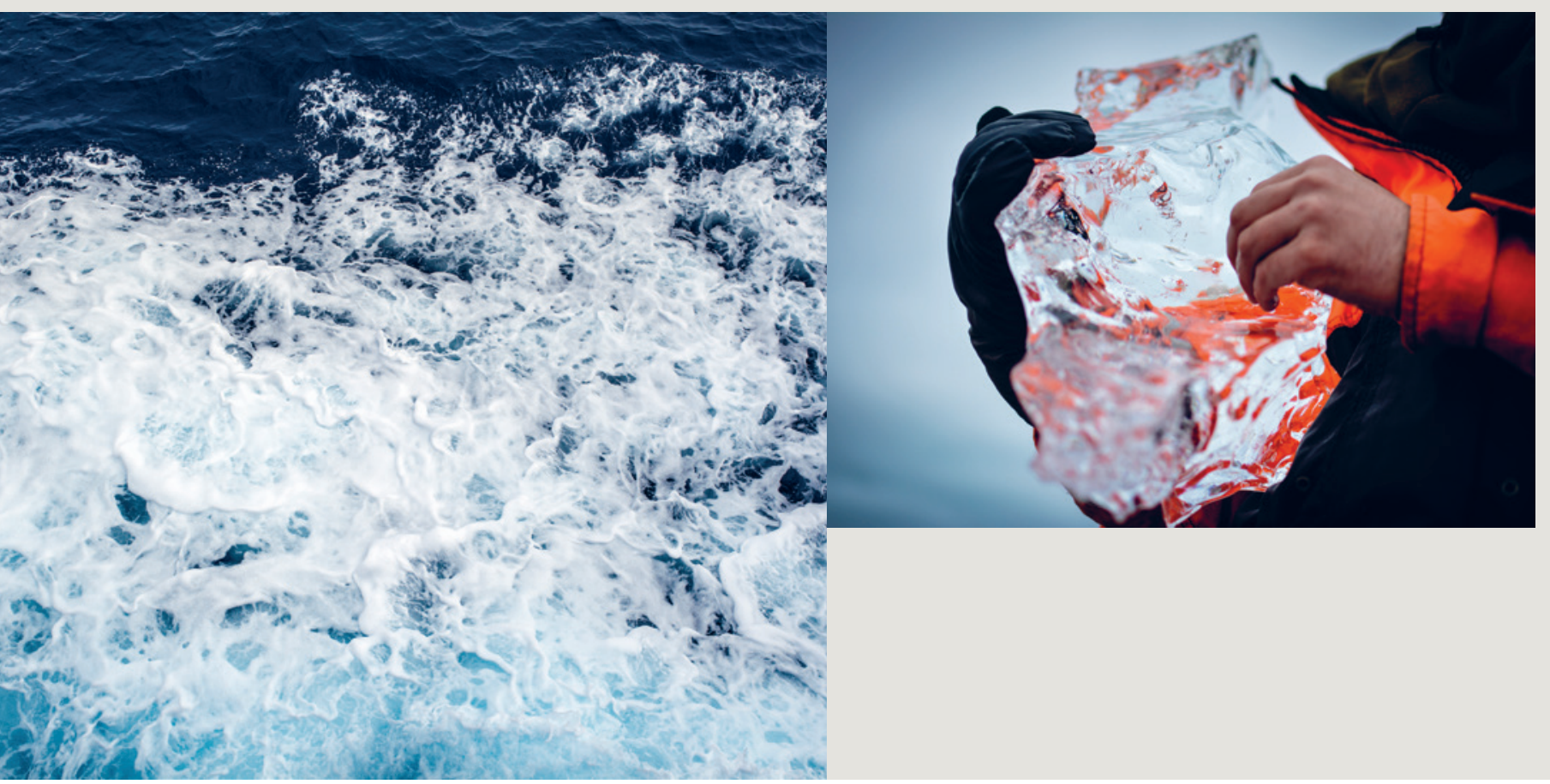


tion plans also include monitoring the development of cable technology, for the purpose of connecting some of the larger cities on the west coast, thus maximising the use of current and future hydropower plants. Connecting parts of the west coast would be especially important if some of the large industrial-scale hydropower potential is realised.

Nukissiorfiit provides energy to 70 cities and villages, of which all but two towns are on their own small isolated grids. Without an interconnected national transmission grid, the intermittency of renewable energy sources like wind and solar challenge the stability of the small local electricity grids.

In July 2017 Nukissiorfiit turned on its first hybrid power plant setup, consisting of 385 solar PV panels, 67 micro wind turbines, battery storage, and a diesel generator for backup. The setup in Igaliku in southern Greenland is intended to power the whole village with renewable energy, at least during the sunny months of the year. It is a pilot project that should provide valuable experience on how to reduce diesel dependency in Greenland's many remote cities and villages.

\section{Extensive untapped hydropower resources}

Greenland's largest hydropower resources are mostly located far away from its towns and villages. However, as the global demand for renewable energy increases, Greenland sees this as an opportunity to attract investors for the development of if its hydropower potentials for use by energy intensive industries. The most promising areas for potential therefore are being continuously monitored and will be promoted internationally.

\section{Renewable options for the Faroes}

The Faroe Islands' Climate Policy, defined in 2009, aims to reduce domestic emissions of greenhouse gases by at least $20 \%$ of 2005 -benchmark levels over the period $2010-2020$. Some $50 \%$ of the islands' electricity already comes from renewable energy sources - mainly hydropower and wind power - although the Faroes' 50,000 residents are still quite dependent on imported oil for heating and transport.

The government is now promoting electricity instead of oil for heating and road vehicles, and striving to further increase the share of renewable electricity production by obtaining more energy from wind, pumped hydropower and the surrounding ocean.

Investments have been made to increase the share of wind power and further investments will be made over the next years in renewable energy production facilities. Hydro-pumping energy storage schemes are planned, and power suppliers are also seeking sustainable ways to obtain renewable tidal energy from the powerful currents that flow around the islands. Also solar energy is being investigated as a potential source.

There is also a significant increase in heat pump installations in the Faroe Islands.

\section{NORDIC-ARCTIC COOPERATION}

The Nordic countries' territories encompass extensive Arctic lands and waters, including the islands of Greenland and Svalbard. To address issues of wider arctic interest the Nordic countries are actively involved in circumpolar and regional organisations including the Arctic Council and the Barents Euro-Arctic Council.

The impacts of climate change are a key issue throughout such cooperation, especially since these impacts threaten both the traditional lifestyles of Arctic indigenous peoples, and the region's fragile biodiversity. Climate issues are also a key theme in the Nordic Council of Ministers' own programme of Arctic cooperation and research initiatives. 


\section{ICELAND \\ UTILISING RICH RESERVES OF RENEWABLE ENERGY}

Iceland's greenhouse gas emissions profile is in many ways unique by international standards. Energy consumption per capita is the highest among OECD countries, with most of the energy consumed by power-intensive industries. In 2014 renewable energy - geothermal and hydropower - together accounted for $87 \%$ of total energy consumption and almost all electricity production and house heating.

Oil is no longer used for heating, and renewable energy has widely replaced fossil fuels in industry. The production of aluminium and other metals accounts for $81 \%$ of total electricity consumption. Fossil fuel consumption rates outside mobile sectors are very low. In 2016 Iceland's fishing fleet accounted for about $28 \%$ of total oil consumption and road transport for over $57 \%$.
The government's long-term Climate Change Strategy defines five key goals with respect to climate change: to meet Iceland's international obligations, reduce fossil fuel use, increase carbon sequestration from the atmosphere through land use changes, encourage research and innovation for low-carbon solutions, and adapt to climate change.

\section{Carbon taxes and low-emission transport}

A national Climate Change Action Plan, approved in 2010, defines mitigation actions to be realised in all sectors of the national economy, overseen by a government climate committee. A new Action Plan is currently in preparation, to help lceland meet its Paris Agreement goals for 2030.

Iceland is not a member of the European Union, but the EU Emissions Trading Scheme has been inte-

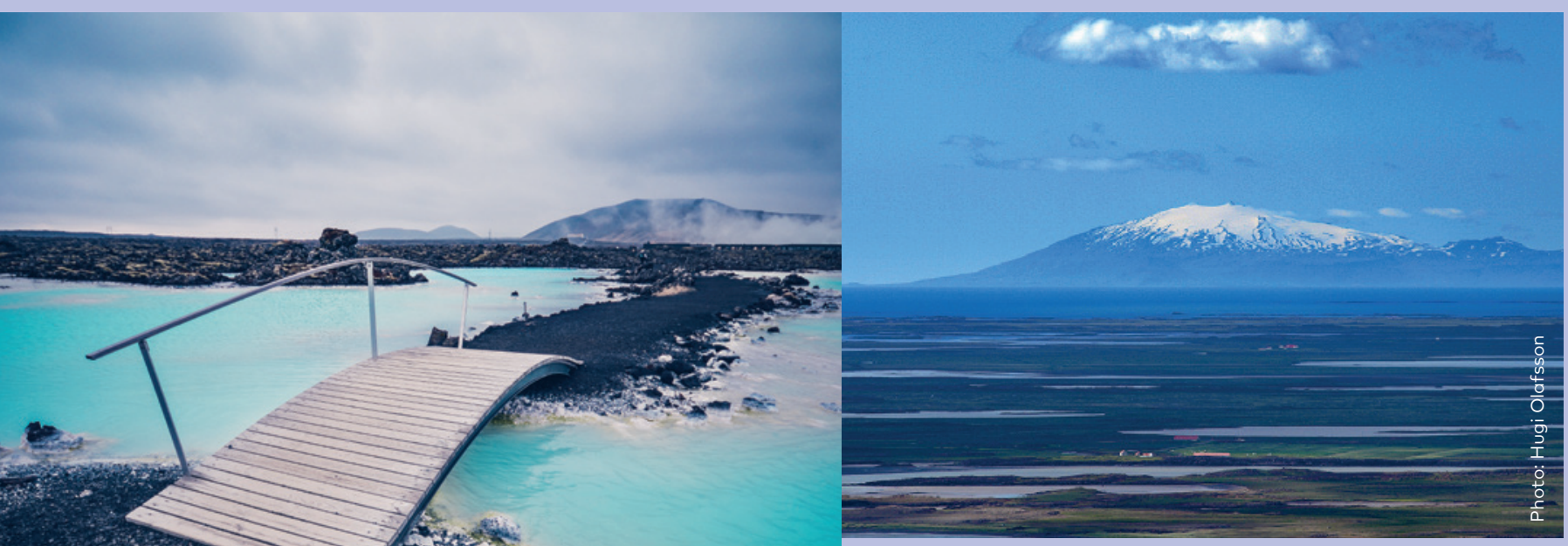

Snæfellsjökull - the glaciers are retreating in Iceland. 
grated into Icelandic legislation. Industrial processes from metal production are the biggest single source of greenhouse gas emissions in Iceland accounting for over $40 \%$ of the total - and these emissions are regulated under the EU-ETS. Fossil fuels have been subject to carbon taxes since 2010, and road vehicle taxes are based on emission levels. These measures together mean that $90 \%$ of Iceland's $\mathrm{CO}_{2}$ emissions are controlled by economic instruments, with an incentive to lower emissions.

With renewables accounting for almost all stationary energy production, future progress to reduce fossil fuel use must focus on cars and ships. Several steps have been taken by national and local authorities to encourage the use of public transport, cycling or walking to work or school. The length of bike paths in Reykjavík and other municipalities has much increased in recent years, and statistics show an increase in cycling. Vehicle and fuel taxes encourage the buying of electric or other low-carbon cars, and the government supports construction of charging stations for electric cars.

\section{Fishing and afforestation}

Emissions from Iceland's key fishing industry have been declining for more than a decade largely due to continuous improvements in fuel efficiency. Fishmeal processing has traditionally used heavy fuel oils for heating, but the industry has largely switched to electricity from renewables, except where technical challenges remain.

In the land-use, land-use change and forestry (LULUCF) sector, Iceland is establishing significant carbon sinks through afforestation and re-vegetation schemes. Such measures should considerably increase Iceland's net LULUCF carbon removals over the coming years and decades. Due to limited opportunities to cut fossil fuel use, Iceland looks at LULUCF as a sector with great potential for climate mitigation.

\section{HEAT FROM THE GROUND}

Iceland has uniquely extensive and accessible reserves of geothermal energy in the form of underground reservoirs of hot water and steam, due to constant volcanic activity along the Mid-Atlantic Ridge, which runs across the country from the south-west to the north-east.

Iceland has long pioneered the use of geothermal energy for local and district heating. Government agencies including the National Energy Authority have actively fostered related research and technological developments. Around $90 \%$ of homes are today heated geothermal (the rest mostly with electricity), as well as many greenhouse cultivation facilities, fish farms and public swimming pools. In recent years the amounts of electricity generated using geothermal energy have risen to about $25 \%$ of Iceland's total electricity supply.

Iceland aims to continue to promote innovation in geothermal technology and use and the export of Icelandic expertise to countries with relatively untapped reserves of geothermal energy. A new project of pumping $\mathrm{CO}_{2}$ into bedrock in a geothermal field, where it turns into a mineral, has shown signs of success. The UN University Geothermal Training Programme in Iceland has provided valuable technical training for many specialists from developing and transitional countries. 


\section{NORWAY COMMITTED TO GLOBAL ACTION}

Norway has through its National Determined Contribution (NDC) under the Paris Agreement committed to a target of at least $40 \%$ emissions reduction by 2030 compared to 1990 . Norway's intention is to fulfil this target jointly with the European Union, which is also welcomed by the EU member states. A key shorter-term target is to reduce global greenhouse gas emissions by an amount equal to $30 \%$ of Norway's 1990 emissions by 2020 . This will be achieved by combining domestic reductions with the financing of emissions reductions abroad through the Kyoto Protocol's flexible mechanisms.

Norway is committed to become carbon neutral by 2030 by reducing domestic emissions and by financing emission reductions abroad that are equivalent to Norway's own remaining emissions.

Norway has adopted a climate act (Lov om klimamå) that enters into force 1 January 2018. The main objective of the act is to promote the implementation of Norway's emission reduction targets as a part of the transition to become a low emission society. The act will have an overarching function in addition to existing environmental legislation. It sets binding emission reduction targets for 2030 and 2050 and makes legally binding the long-standing political aim to become a low emission society by 2050 .

Though not a member of the European Union, Norway participates in the EU Emission Trading System (ETS), through the EEA Agreement. The scheme covers installations in the industry and energy sector. An agreement with the $E U$ on joint fulfilment of our 2030 targets will cover cooperation in sectors not included in the ETS (mainly transport, agriculture, buildings and waste). Norway is also committed to a national 2020 target increasing the share of renewable energy to $67.5 \%$ of total energy consumption, pursuant to the Renewables Directive, from about $64.5 \%$ in 2012. Through one of the cooperation mechanisms under the Renewables Directive, Norway and Sweden have a common certificate scheme that will increase renewable electricity production by 28.4 TWh by 2020, compared to 2012.

\section{A GROUND BREAKING CLIMATE AND FOREST INITIATIVE}

Norway's International Climate and Forest Initiative supports global efforts that reduce greenhouse gas emissions from deforestation and forest degradation in developing countries (REDD+). Forest and land use emissions are estimated to account for about $10 \%$ of global net anthropogenic greenhouse gas emissions. It represents an even bigger part of the near term potential solution by simultaneously halting forest loss and restoring forest lands. This is also among the most cost-effective ways to mitigate climate change, and contributes to most of the sustainable development goals.

Since 2007 Norway has been the largest contributor of finance for REDD+ globally. Through 2016 Norway had disbursed NOK 20 billion, and is committed to continue allocating NOK 3 billion (EUR 350 million) a year until 2020. These funds are used to pay for verified emission reductions in partner countries, to finance efforts to build up global and national REDD frameworks, improve national forest monitoring systems and global transparency and to support civil society and indigenous peoples around the world. 
Enova - a state-owned enterprise - has since over 15 years played an increasing role in the development of an energy supply system for the future and the transition to a low-emission society by funding projects and providing advice. Enova's primary objective is to fund projects to reduce greenhouse gas emissions and strengthen security of energy supply, and to support the development of technology that in the longer term will yield further cuts in greenhouse gas emissions.

Combined, the carbon dioxide $\left(\mathrm{CO}_{2}\right)$ tax and $\mathrm{EU}$ ETS cover more than $80 \%$ of Norwegian GHG emissions. Norway's advanced environmental and energy taxation system includes taxes on mineral products including petrol and gas, petroleum-based vehicle fuels, that have been imposed since 1991. In addition to being included in the ETS, emissions from Norway's extensive offshore oil and gas industry are subject to a $\mathrm{CO}_{2}$ tax to give the industry a further incentive to limit emissions. In December 2015 the Green Tax Commission delivered a report on how a green tax reform can be used to secure reduced greenhouse gas emissions, improved environmental conditions and sustainable economic growth.

Norway has committed NOK 1.6 billion to the Green Climate Fund between 2015-2018. At COP21 we announced that we will increase our GCF contribution before 2020, and double it if the fund develops a framework that secures verified emission reductions from reduced deforestation and forest degradation. Norway is also a strong supporter of carbon pricing. We support the operationalization of the Transformative Carbon Asset Facility (TCAF), a results-based instrument that will trigger more ambitious mitigation action in developing countries.

\section{ELECTRIC CARS APPEARING ON THE ROADS}

To reduce emissions in the transport sector, Norway has been actively promoting zero emission cars. More than 100,000 battery electric cars are today registered to run on Norway's roads. In the first half of 2017 battery electric models accounted for almost $19 \%$ of new car sales in Norway - a higher share than any other country in the world. Close to $50 \%$ of new passenger cars sold in Norway are either battery electric, plug in hybrid or hybrid vehicles. An impressive network of more than 2,000 charging stations has already been built. The building of charging infrastructure benefits from Norway's relatively inexpensive renewable electricity. The Norwegian government has also introduced a support scheme for a rapid charging network along the main highways.

Today, Norway has the world's highest share of zero emission vehicles in its passenger car fleet. This development can be partly explained by long-term incentives for zero emission cars. Incentives such as zero registration tax and free toll roads were introduced in the 1990s and zero VAT was introduced in the early 2000s. Nevertheless, the success story of zero emission cars in Norway could never have happened without technological development, making zero emission vehicles better and cheaper. For instance, battery electric cars had a market share of $2.9 \%$ of new passenger cars sold five years ago. In the first half of 2017, the battery electric vehicles had almost a $19 \%$ market share.

The Norwegian government has set itself a target that all new passenger cars sold in 2025 shall be zero emission vehicles. In Norway, the purchase of zero-emission cars should continue to be more economically favourable than the purchase of conventional cars. Still, improvements in technological maturity, in a way that zero emission vehicles will be competitive in relation to conventional vehicles, is a precondition for the 2025 target. 


\section{SWEDEN INVESTING IN CLIMATE ACTION AND JOBS}

Sweden aims to become one of the first fossil-free welfare nations in the world. The Swedish parliament has adopted a climate policy framework including a climate act, new climate goals and an expert climate policy council. New national targets have been set of reducing emissions with $59 \%$ compared to 2005 by 2030 . By 2045 Sweden is set to have zero net emissions of greenhouse gases. Emissions from domestic transport are to be reduced by at least $70 \%$ by 2030 compared with 2010 . An expert climate policy council will provide independent assessments of how the Swedish government's policy is compatible with the climate goals.

The climate policy framework will provide the longterm conditions for business and society to implement the transition needed to solve the challenge of climate change. For the first time, Sweden will

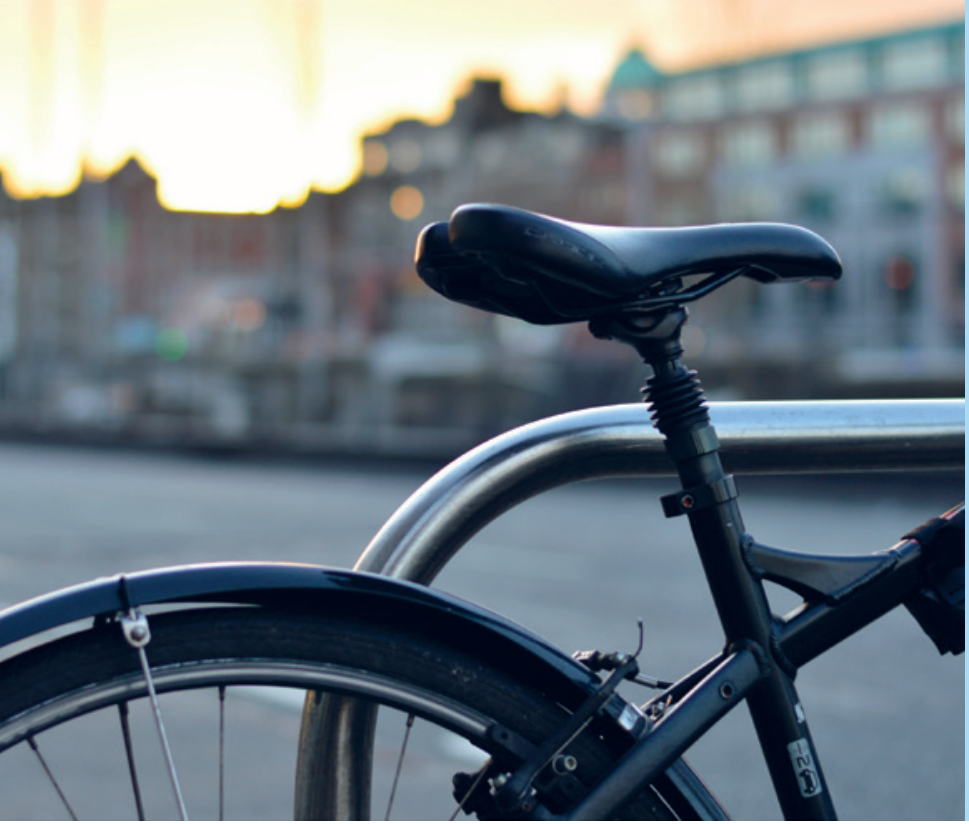

have an act stating that each government has an obligation to pursue a climate policy based on the climate goals adopted by parliament. Each government must also clearly report on the progress of its efforts. The reform is a key component of Sweden's efforts to comply with the Paris Agreement.

\section{Green energy on the rise}

Sweden's long-term ambition is that the national energy system should be based on $100 \%$ renewable energy. Renewable energy sources, especially hydropower and biofuels, already account for $54 \%$ of total energy use, so Sweden's renewables target for 2020 has already been achieved. This success is partly thanks to a market-based electricity certification scheme introduced in 2003. This scheme obliges electricity suppliers to obtain a certain quota of their power from renewable sources, which will be increased every year until 2020. At the same time, subsidies are provided to encourage climate-friendly investments and innovations.

Most of the future increase in renewable energy will come from a steadily expanding wind power programme, the spread of transport biofuels, and the increased use of heat pumps and renewable energy for heating. 


\section{EFFICIENT DISTRICT HEATING - AND COOLING}

Sweden's progressive electricity certification and energy and carbon taxation policies have favoured combined heat and power production (CHP) and alternatives to fossil fuels for heating schemes, leading to radical reductions in emissions from the heating of buildings. In CHP plants $80-90 \%$ of the primary energy in the fuel may be converted to energy, compared to about 50\% when only heat is generated.

District heating schemes now meet more than half of Sweden's heating needs. Such schemes exist in all communities with more than 10,000 inhabitants, as well as many smaller settlements. Since the 1980s Sweden's total district heating supply has doubled, while the fuel mix has switched from about $90 \%$ fossil fuels to 90\% non-fossil fuels today. Sweden's growing district heating networks currently have a total of $20,000 \mathrm{~km}$ of heating pipes.

Many schemes exploit readily available surplus heat from industrial processes or power plants. Residual biomass and other wastes are also increasingly used to fuel district heating systems, or to produce biogas, instead of being sent to landfill. Many district heating plants are able to use various fuels flexibly. Sizeable district heating systems are much more efficient and less polluting than having many boilers in individual buildings.

Technologies developed for district heating are also increasingly being used for district cooling in many Swedish towns. Perhaps surprisingly, Stockholm is among the world's leading cities in the use of district cooling, together with Abu Dhabi and Paris.

\section{WORKING TOWARDS FOSSIL-FREE TRANSPORTATION}

Sweden has already exceeded the EU's 2020 target of $10 \%$ renewable energy in the transport sector and preliminary data shows that the share in 2017 was nearly $31 \%$ calculated in accordance with the related EU directive. Without applying double counting of certain fuels, the share is $19 \%$.

This progress can largely be attributed to policies such as EU emission standards for new vehicles and progressively raised national carbon taxes on fossil fuels, which have encouraged improvements in cars' fuel efficiency and the adoption of sustainable biofuels.

Emissions from transportation however still make up roughly a third of Sweden's total greenhouse gas emissions. Emissions from cars were 14\% lower in 2015 compared to 1990, but any reductions accomplished by energy efficiency and the use of biofuels have been offset by, and are currently not enough to compensate for, the increased levels of transport.

Sweden aims to further reduce emissions from the transport sector, by planning of cities to reduce demand for transport, by encouraging the use of public transport, by promoting a shift from road to rail and sea transportation, and by developing more efficient vehicles and renewable fuels. The government is currently upgrading Sweden's railways and working with municipalities to enhance local public transport systems and set up more charging stations for electric vehicles.

Economic incentives to boost sales of fuel-efficient car models include reduced vehicle tax rates for "eco-cars" and a "super bonus" for purchasers of vehicles with the lowest emissions. Furthermore the Swedish government has proposed a "bonus-malus" incentive system aimed at achieving a change in the sale of new vehicles. 

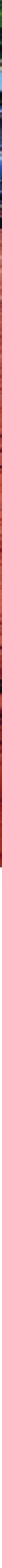

Photo above: Major investments in road improvement are urgently needed in the rural regions of Lao PDR. 


\section{JOINT NORDIC ACTION}

In addition to realising their national strategies and measures, the Nordic countries also pool their resources to combat climate change through various joint Nordic initiatives.

The Nordic Council of Ministers (NCM) is the official inter-governmental body overseeing Nordic cooperation. Climate issues are prominent in the Nordic prime ministers' initiative called "Nordic Solutions to Global Challenges", which is realised by the NCM. The Cooperation on Nordic solutions includes among other themes activities within climate solutions. Here the activities focus on developing models and tools for reforming the subsidy system to fossil fuels (FFSR), this being based on earlier Nordic cooperation within the theme, as well as looking into how progressive Nordic solutions in environmental economics, green technology and environmental policies can be deployed and scaled up globally.

The Nordic Development Fund (NDF) provides funds to help low-income countries in Africa, Asia and Latin America directly address the causes and consequences of climate change. Funds are used for mitigation and adaptation activities, typically through co-financing cooperation with multilateral development banks (MDBs) and other financial institutions. NDF's contribution typically amounts to 3-10 million euros per project. NDF's capital is allocated from the development budgets of the Nordic countries. The fund's assets currently amount to some EUR 860 million.

NDF actively seeks opportunities that match the focus areas, and where it can add significant value beyond financing, either in collaboration with other financiers or through initiatives where it can take a larger or a more independent role. Co-financing and resource mobilisation with other entities may also be considered.

The climate impacts of NDF-backed projects are carefully screened and NDF seeks to utilise innovative funding mechanisms, particularly in relation to private sector developments. NDF's contributions provide vital leverage for the preparation, piloting and realisation of exploratory and transformative climate change solutions addressing current and emerging issues.

\section{The Nordic Environment Finance Corporation (NEFCO) has more than 25 years of experience} in financing projects outside the Nordic region, but with positive environmental/climate impacts for the Nordic countries and beyond. NEFCO's green financing is targeted at small and medium-sized private and public projects (SMPs) with demonstration value. Many of the numerous SMPs financed by NEFCO over the years are characterised by a pioneering spirit and aimed at testing the application of Nordic solutions with up-scaling possibilities - in local, non-Nordic circumstances.

Today, an important part of NEFCO's green financing is focused on public energy efficiency projects and the internationalisation of Nordic companies within the environmental sector. Both of these activities generate at the same time environmental/climate benefits and positive economic returns to the municipalities and the companies involved, enabling them to grow and make new sustainable investments. For example, annual surveys of the effects of the financing support provided by NEFCO through the Nordic Project Fund - Nopef, financed by the Nordic Council of Ministers, show that the medium term effects of this internationa- 
lisation facility generate almost 500 jobs annually, of which $15 \%$ are in the Nordic countries.

In other words, the internationalisation of green growth companies is benefitting the environment and climate, and creating new jobs in the Nordic countries as well as in the countries in which the companies choose to establish themselves.

Through its extensive Trust Fund activities, NEFCO facilitates the financing of Arctic Council projects related to climate change, including a number of projects addressing short-lived climate pollutants (SLCP) via its management of the Arctic Council Project Support Instrument (PSI), which in addition to Nordic contributions include contributions from Russia and the US. Significant climate-related Trust Funds managed by NEFCO include also the Norwegian Carbon Procurement Facility (NorCaP) and the NEFCO Carbon Fund (NeCF). Using funds made available through its pioneering public-private carbon fund activities, NEFCO has supported many renewable energy and energy efficiency pro- jects in Asia and Latin America as well as Eastern Europe by providing them with access to carbon finance through the purchase of various types of certified emission reductions.

In 2016, climate investments and carbon finance provided by NEFCO, or through Trust Funds management by NEFCO, reduced carbon dioxide emissions by a total of 8.5 million tonnes (direct + indirect). The bulk of these savings relate to renewable energy and energy efficiency measures.

\section{Technology transfer partnerships}

NEFCO typically works in close partnership with its private and public investors and beneficiaries. In relation to its financing of public investments, NEFCO, through the application of a flexible hands-on approach, has developed an ability to assist borrowers efficiently in the identification, development, implementation and administration of green projects and to make them attractive also to other financiers, including other government-financed financiers/facilities as well as larger Inter-

NEFCO financed projects contributed to 5.1 million tonnes direct carbon dioxide and 514 tonnes nitrogen oxide emission reductions in 2016.

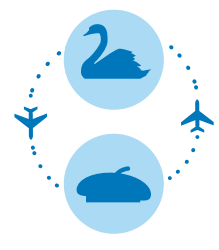

$\mathrm{CO} 2$ direct + CER 5.1 million tonnes $=$

10 million people travelling from Helsinki to Paris and back by aircraft

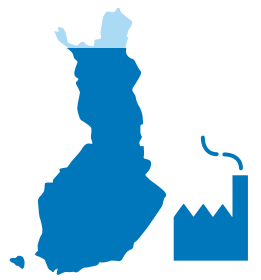

NOx 514 tonnes $=$

$90 \%$ of the emissions from Finnish industrial processes in 2014

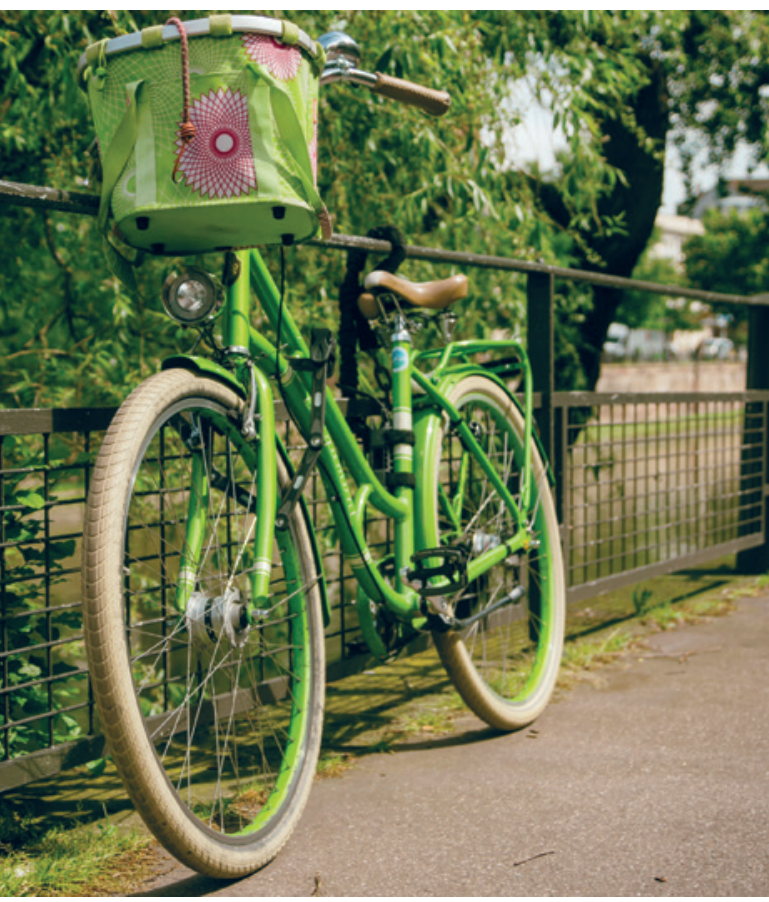


national Financial Institutions, such as EBRD. In this way NEFCO's finance also contributes to local capacity building and the transfer of knowledge and technology within areas where Nordic Solutions are particularly relevant. NEFCO is in dialogue with Green Climate Fund aimed at obtaining accreditation to manage its funds and be able to blend them with NEFCO's own funding and other funds NEFCO holds in trust.

\section{Financing innovation}

NDF also finances the Nordic Climate Facility (NCF). NCF is a challenge fund that finances innovative climate change projects. Projects are implemented through partnerships between Nordic and local organisations in an eligible NCF country. Financing is allocated on a competitive basis with calls for proposals arranged annually. Since 2009, six calls for proposals have been organised with over 70 projects realised. NCF can provide financing of between EUR 250,000 and 500,000. NCF was in its initial phase jointly administered by NDF and NEFCO.
Nordic governments and NEFCO also fund the NCM's Nordic Partnership Initiative on Up-scaled Mitigation Action, a pilot emission reduction program in Peru. NDF has funded a similar pilot initiative in Vietnam. These pilot programmes aim to serve as forerunners for the international financing of nationally appropriate mitigation actions (NAMAs).

In Peru the goal has been to reduce emissions from waste management by finding sustainable uses for waste, aided by increasing private sector involvement. In Vietnam the focus has been on the energy-intensive cement production sector, which is the largest emitter of industrial greenhouse gases in this rapidly developing country.

\section{Financing sustainable Nordic and Baltic projects} The Nordic Investment Bank (NIB), another international financial institution that supports the development of a low-carbon economy, is owned jointly by the Nordic and Baltic countries. NIB provides long-term loans to private and public sector partners in the Nordic and Baltic regions

\section{$\mathrm{CO}_{2}$ reduction}

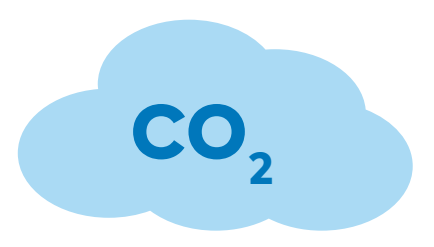

NIB loans in 2016 contributed to an annual reduction of 280,000 tonnes of $\mathrm{CO}_{2}$ emissions, and to an increase of 6,000 tonnes of $\mathrm{CO}_{2}$ emisssions.

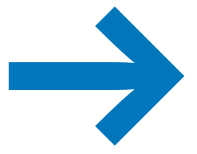

This reduction equals taking 228,000 cars off the road. 
for projects that improve competitiveness and the environment.

Many NIB-backed projects aim to increase the use of renewable energy, including geothermal power in Iceland, wind power in Denmark and Sweden, and wood energy in Finland. NIB has also financed energy efficient infrastructure and public transport schemes, including improvements to rail transport systems in Sweden, Finland, Lithuania and Latvia.

\section{Coordinated action on key issues}

Nordic inter-governmental co-operation on environmental issues including climate change is overseen by the Nordic Council of Ministers for the Environment (MR-M), by 1 January 2018 the Nordic Council of Ministers for the Environment and Climate. The MR-M's members, who come from the five Nordic countries and three autonomous regions, meet regularly to coordinate strategic issues, activities, funding and practical cooperation. This collaboration helps the Nordic countries pull their collective weight in international forums.
Several of the MR-M's key activities relate to climate issues. The Nordic Working Group for Global Climate Negotiations (NOAK) coordinates Nordic efforts to contribute to an ambitious and effective implementation of the UNFCCC and its Paris Agreement.

NOAK regularly organises related meetings, side events and workshop supporting Nordic and international negotiators in the UN climate negotiations, as well as projects on issues of current interest with regard to negotiations, ranging from international initiatives and land use issues to climate finance and raising ambition.

The Nordic Council of Ministers' cross-sectorial Working Group on Environment and Economy (MEG) funds Nordic projects that review how economic instruments can be used to help mitigate climate change and promote sustainable green growth.

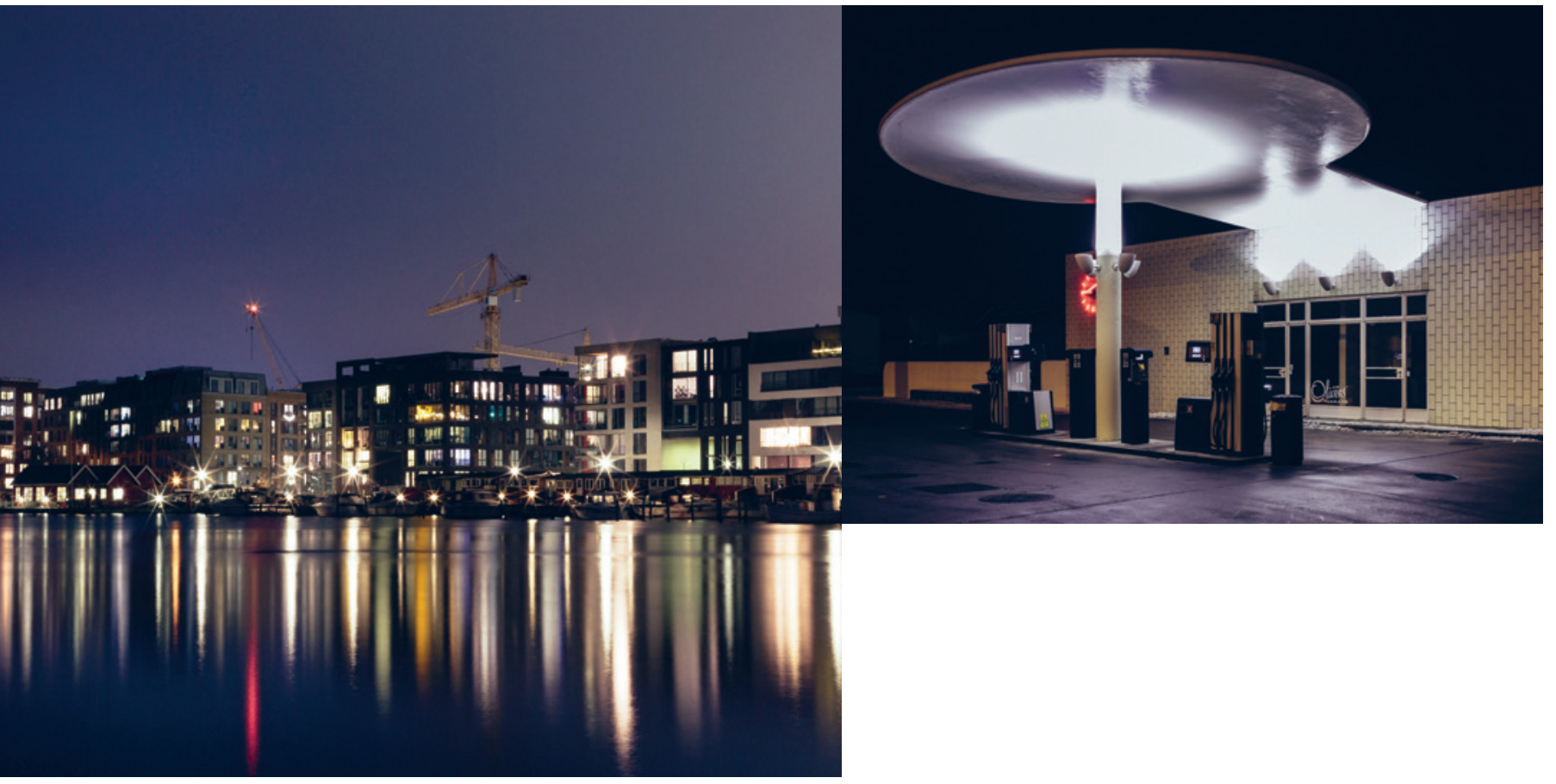




\section{NORDIC SUPPORT FOR CLIMATE-FRIENDLY DEVELOPMENT}

The Nordic Development Fund (NDF) provides cofinancing for projects that contribute to climate change mitigation and adaptation in 18 selected developing countries.

\section{Supporting microfinance in Ethiopia}

An example of how NCF provides co-financing for the transfer of Nordic climate-related knowhow was a project promoting clean energy through microfinance in Ethiopia. Working with the support of Nordic Partner Gaia Consulting Oy over a 30-month project period, three Ethiopian microfinance institutions have established a business concept that increases access to affordable clean energy technologies (CET) for low-income households and microenterprises in the East African country.

The project has developed the entire supply chain for high-quality, clean energy technologies for low-income markets. The project partnership trained the microfinance institutions and clean energy technology providers in the execution of the new credit mechanism.

The project has contributed to climate change mitigation by reducing GHG emissions from energy generation through replacing unsustainable energy sources with renewable options. The piloting operations conducted during the project achieved direct emission reductions in the range of $3,500 \mathrm{t} \mathrm{CO}$, a figure that will multiply as the business model is taken into use in other branches of the participating MFIs.
Thus far, the Ethiopian microfinance sector has not responded to the national need, for example, for including green energy financing activities in their operations. The approach responds to the urgent need to facilitate a further collaboration between energy system suppliers and financial services providers to ensure that the technologies are appropriate and affordable for those living on low incomes.

\section{Laos project mixes grant and loan funding}

Contributions to a recently launched road improvement project in Lao PDR represent a significant milestone in terms of the diversity of financial instruments used by NDF. The grant portion of the NDF funding, amounting to EUR 5 million, will be used to map out the project activities, initiate better road design and maintenance standards, and build up capacity for road management; while a parallel EUR 6 million loan will be used to fund civil works in the six project regions in Lao PDR.

As a landlocked country with poorly navigable rivers and an extremely limited rail network, Lao PDR is highly dependent on roads for the transportation of goods and people. The likelihood of more frequent extreme weather events means that road construction and maintenance must be upgraded to ensure people's access to essential services, and reduce the need for expensive and disruptive emergency repairs. The project aims to rapidly improve the condition of regional roads in selected provinces, and make them more resilient to forecasted climate impacts. 


\section{Reviews of urgent climate topics}

The MR-M's Climate and Air Pollution Group (KOL) runs projects designed to combat climate change and limit the harmful impacts of trans-boundary air pollution in the Nordic and Arctic regions. Recent KOL reports have focused on issues including Nordic solutions to global climate challenges through the Nordic Green to Scale project, Nordic climate policies, carbon footprints and the causes and consequences of climate change in NordicArctic regions.

Another important priority for $\mathrm{KOL}$ is emissions of short-lived climate pollutants (SLCPs) such as methane, tropospheric ozone and black carbon in the form of soot. Such pollutants contribute to warming in sensitive regions like the Arctic but have also consequences for air quality and health. Related Nordic initiatives have been launched to help control emissions of soot and other SLCPs, and spread knowhow on cost-effective measures.

The Nordic countries are pro-actively driving international initiatives to reduce GHG emissions, trans-boundary air pollution and SLCP emissions through different international forums including the UN Climate Convention (UNFCCC), the Arctic Council, the Air Convention (CLRTAP) and the Climate and Clean Air Coalition to Reduce Shortlived Climate Pollutants (CCAC).
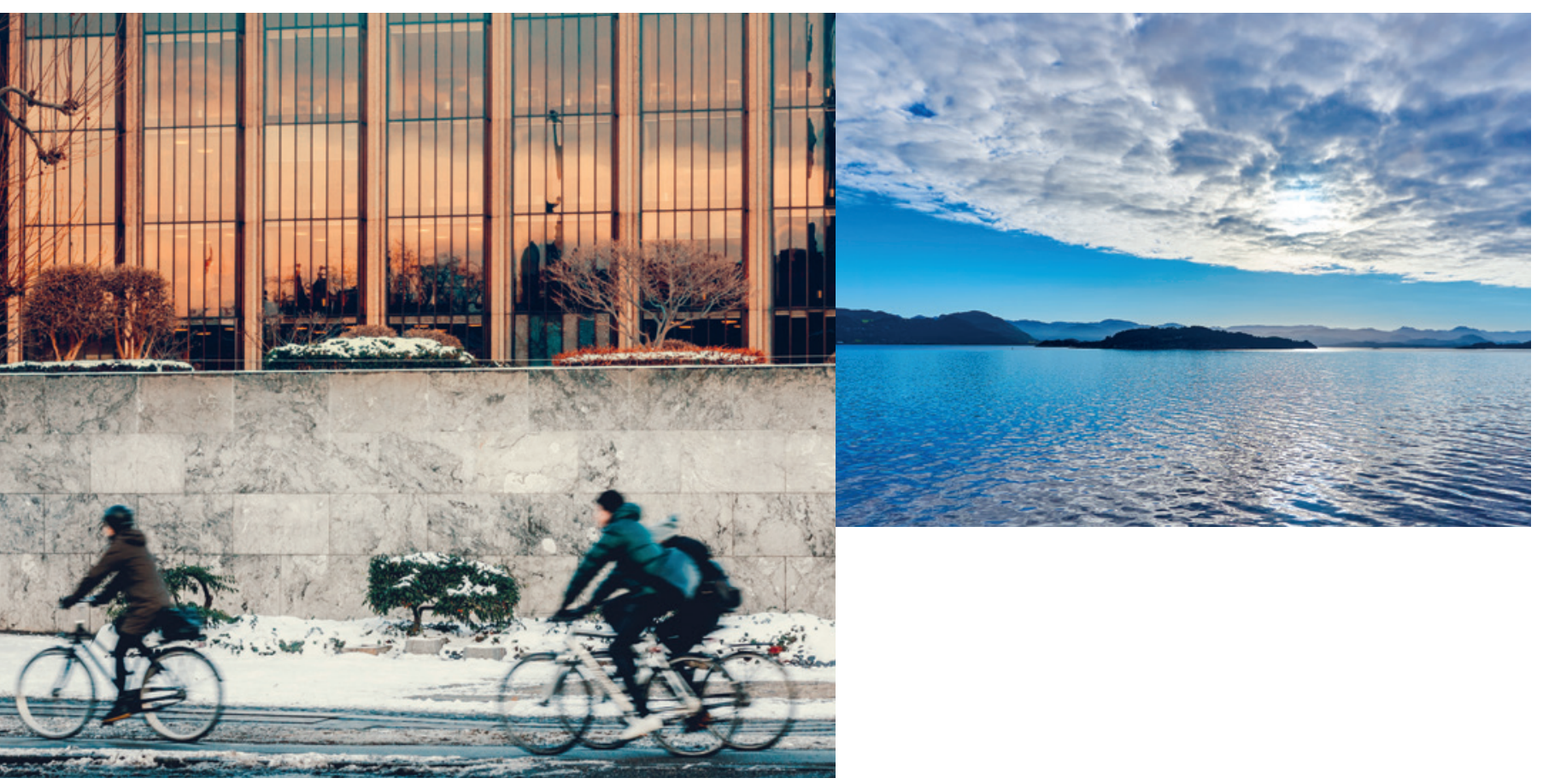


\title{
KEY NORDIC ORGANISATIONS AND INITIATIVES
}

\author{
The Nordic Council of Ministers coordinates progress on climate-friendly \\ development through its Nordic Solutions to Global Challenges \\ www.norden.org/nordicsolutions
}

The Nordic Way web magazine features examples of Nordic Solutions on Green Growth www.nordicway.org

The Nordic Development Fund (NDF) co-finances climate-friendly developments in Africa, Asia and Latin America www.ndf.fi

The Nordic Environment Finance Corporation (NEFCO) invests in projects with positive climate and environmental impacts mainly in neighbouring regions of Central and Eastern Europe, and in climate projects globally www.nefco.org

The Nordic Climate Facility provides co-financing for the transfer of Nordic climate-related knowhow to developing countries www.ndf.fi

The Nordic Investment Bank (NIB) promotes sustainable growth by financing projects that improve competitiveness and the environment in the Nordic and Baltic regions www.nib.int

Nordic Energy Research is a platform for cooperative energy research and policy development under the Nordic Council of Ministers www.nordicenergy.org 
Nordic Council of Ministers

Nordens Hus

Ved Stranden 18

DK-1061 Copenhagen

www.norden.org

\section{NORDIC ACTION ON CLIMATE CHANGE}

This publication presents actions taken by the Nordic countries to speed the transition to a sustainable low-carbon society. It shows how sustainable development is possible, with strong climate policies contributing to economic growth and job creation as well as environmental improvements. The Nordic countries successfully demonstrate how ambitious climate change mitigation targets and policies can be com-bined with high levels of human development. 